\title{
TEXTURE, COLOR, VITAMIN C AND REDUCING SUGAR CONTENT OF MILK TOFFEE ADDED WITH Dracaena angustifolia LEAVES AQUEOUS EXTRACT AS NATURAL COLORANT
}

\author{
Herly Evanuarini*1), Dicky Tri Utama $^{1)}$, Firman Jaya ${ }^{1)}$ \\ 1) Department of Animal Products Technology, Faculty of Animal Science, Universitas Brawijaya, Malang, \\ Indonesia 65145 \\ E-mail: herlyfptub@ub.ac.id
}

Submitted 2 February 2020; Accepted 29 February 2020;

\begin{abstract}
The leaf of Dracaena angustifolia has been used widely not only as natural food colorant but also as a natural source of vitamin $C$. The objective of this study was to obtain the best addition level of Dracaena angustifolia leaves aqueous extract as natural food colorant for milk toffee based on its effect on texture, color, vitamin $\mathrm{C}$ and reducing sugar content. Milk toffee was formulated with different addition levels of Dracaena angustifolia leaves aqueous extract as treatment; $3 \%, 4 \%, 5 \%, 6 \%$ on weight/milk volume basis, and compared to control $(0 \%)$. Higher addition level of Dracaena angustifolia leaves aqueous extract to milk toffee resulted in higher $(\mathrm{P}<0.01) \mathrm{L}^{*}, \mathrm{a}^{*}, \mathrm{~b}^{*}$ values, and softer texture. Vitamin $\mathrm{C}$ and reducing sugar content were increased by the addition of $4 \%$ extract. However, there were no further differences on vitamin $\mathrm{C}$ and reducing sugar content when the addition level was increased up to $6 \%$. Therefore, among treatments, the highest addition level used in this study (6\%) is suggested as the best addition level according to texture, color, vitamin $\mathrm{C}$ content and reducing sugar content of milk toffee. The addition of natural food colorant, which contains antioxidant, e.g. Dracaena angustifolia leaves aqueous extract, also promotes the diversification of milk toffee.
\end{abstract}

Keywords: Antioxidant; confectionary; natural food colorant; dracaena angustifolia leaves 


\section{INTRODUCTION}

Milk is one of perishable food, which is nutritious, but the quality is easily degraded when it is inappropriately handled and processed. Thermal process, fermentation and dehydration are the major processing techniques that are aimed to preserve milk (Amit et al., 2017). Milk toffee is one of dairy products that is thermally processed and added with sugar. The characteristics of milk toffee are soft in texture, having cream-like color, and nonsticky. Most of milk toffee in market is the original one and less attractive to consumer. Further, the thermal process may lead to nutrient loss. The addition of natural dye possessing antioxidant capacity is thus necessary to make the milk toffee attractive and prevent the loss of nutrient. Marlina et al. (2018) reported that the addition of red dragon fruit pulp (Hylocereus polyrhizus) to milk toffee increases the acceptability. Moreover, Hayati et al. (2018) found that the addition of Moringa oleifera leaves to milk toffee increases its nutrition value. However, the utilization of Dracaena angustifolia leaves as natural colorant for milk toffee has not been well informed. Anggraini and Nabillah (2018) mentioned that Dracaena angustifolia leaves contain antioxidants such as chlorophyll, vitamin C, phenolic and flavonoid compounds. Therefore, the addition of Dracaena angustifolia leaves aqueous extract to milk toffee could prevent the loss of nutrient and improve the appearance.

Natural pigments, e.g. carotenoids, anthocyanins, betalains, actinorhodins and chlorophylls, derived from plants, algae and cyanobacteria are generally regarded as safe materials for food as compared to synthetic dye (Özkan and Bilek, 2014). Dracaena

\footnotetext{
*Corresponding author:

Herly Evanuarini

Email: herlyfptub@ub.ac.id

Department of Animal Products Technology, Faculty of Animal Science, Universitas Brawijaya, Malang, Indonesia 65145
}

angustifolia plant is abundant in population, grows well in tropical climate and is utilized as natural food colorant. Dracaena angustifolia leaves contain green pigment in chloroplasts (Aryanti et al., 2016). Dracaena angustifolia leaves extract has more intense green color and less aromatic than Pandanus amaryllifolius leaves extract (Andesna and Elida, 2019), thus could not dominance the milk and caramel aroma from milk toffee. Therefore, the objective of this study was to obtain the best addition level of Dracaena angustifolia leaves aqueous extract for producing milk toffee with attractive appearance and containing antioxidant.

\section{MATERIALS AND METHODS}

\section{Materials}

Fresh milk was obtained from local dairy cooperative unit. Dracaena angustifolia leaves, agar-agar powder, and sucrose were purchased from local market. Distilled water, starch, iodine, ascorbic acid, lead acetate, sodium carbonate, potassium iodide $10 \%$, sulfuric acid and sodium thiosulfate were purchased from local supplier.

\section{Dracaena angustifolia leaves aqueous extract preparation}

The aqueous extract of Dracaena angustifolia leaves was prepared according to a method described by Jokopriyambodo et al. (2014) with modification in filtration conditions. The Dracaena angustifolia leaves were washed using flowing water and cut into $1 \mathrm{~cm}$-cut size. The leaves were weighed and blend with distilled water at 2:5 (weight/volume) ratio for $5 \mathrm{~min}$ at medium speed using a food processor (HR7754, Philips, Eindhoven, Netherlands).

How to cite:

Evanuarini, H., Utama, D. T., \& Jaya, F. (2020). Texture, Color, Vitamin C and Reducing Sugar Content of Milk Toffee Added with Dracaena angustifolia Leaves Aqueous Extract as Natural Colorant. Jurnal Ilmu dan Teknologi Hasil Ternak, 15 (1), 21-30 
The slurry was filtered using cheesecloth twice. The aqueous extract was collected and used immediately for milk toffee preparation.

\section{Milk toffee preparation}

Fresh whole milk was pasteurized at $80^{\circ} \mathrm{C}$ for 15 min on a non-stick pan and cooled down until the final temperature reached $50^{\circ} \mathrm{C}$. Sucrose ( $25 \%$ of milk weight) and agar-agar powder $(0.14 \%$ of milk weight) were mixed in part of pasteurized milk until well dissolved. The mixture was added to the rest of the milk, mixed until the consistency of milk toffee mixture got condensed (before got caramelized) and added with Dracaena angustifolia leaves aqueous extract. The toffee mixture was poured into sheet pan. Once the toffee hardened, it was cut into $2 \times 1 \mathrm{~cm}^{2}$, wrapped with parchment paper and stored at ambient temperature until analysis.

\section{Texture analysis}

The penetration force representing the hardness $(\mathrm{N})$ of milk toffee was measured using a texture analyzer (CT-03, Brookfield, MA, USA). The samples were compressed to $90 \%$ of original height at a constant speed of $0.1 \mathrm{~mm} / \mathrm{s}$ using a $35-\mathrm{mm}$ cylinder probe at ambient temperature. The pre-test and post-test speed were $1.0 \mathrm{~mm} / \mathrm{s}$ and $10 \mathrm{~mm} / \mathrm{s}$, respectively (Al-Rawahi et al., 2005).

\section{Color measurement}

The instrumental surface color of the gels was recorded by measuring International Commission on Illumination's system for lightness (CIE L*), redness (CIE $\mathrm{a} *$ ), and yellowness (CIE $\mathrm{b} *$ ) using a color reader (CR-400, Konica Minolta Inc., Tokyo, Japan). The light source of illuminant $\mathrm{C}(2 \circ$ observer $)$ with attached- closed cone and $8 \mathrm{~mm}$ aperture was calibrated using a white plate $(\mathrm{Y}=93.6$, $\mathrm{X}=0.3134, \mathrm{y}=0.3194)$.

\section{Vitamin $C$ content measurement}

Vitamin $\mathrm{C}$ content of milk toffee was measured using iodometric titration method (Spínola et al., 2013). Sample was weighed $(10 \mathrm{~g})$, extracted using maceration method using distilled water $(50 \mathrm{~mL})$ and filtrated through filter paper (Whatman No.42, GE Healthcare, IL, USA). The extract (5 mL) was added with $2 \mathrm{~mL}$ of $1 \%$ starch solution and homogenized using vortex mixer for $5 \mathrm{~s}$. The mixture was then titrated with $0.1 \mathrm{~N}$ potassium iodate until the color changed to dark blue and the color had been stable for more than $60 \mathrm{~S}$. Each $\mathrm{mL}$ of potassium iodate used is equivalent to $0.8806 \mathrm{mg}$ of $\mathrm{L}^{-}$ ascorbic acid.

\section{Reducing sugar content measurement}

Reducing sugar content was determined using Luff-Schoorl reagent (Marrubini et al., 2017). Sample was weighed $(5 \mathrm{~g})$ and added with $100 \mathrm{~mL}$ distilled water. The mixture was added with lead acetate for purification. After purification, sodium carbonate was added to remove lead. The mixture was then diluted with distilled water until the volume reached $250 \mathrm{~mL}$. The solution $(25 \mathrm{~mL})$ was added with $62.5 \mathrm{~mL}$ Luff-Schoorl reagent, boiled for $10 \mathrm{~min}$ using hot stones and cooled down. Later, $15 \mathrm{~mL}$ of $20 \%$ potassium iodide and $25 \mathrm{~mL}$ of $26.5 \%$ sulfuric acid were added. The solution was titrated with $0.1 \mathrm{~N}$ sodium thiosulfate until became yellow, then added with $1 \%$ starch until blue color disappeared. Blank (distilled water added with Luff-Schoorl reagent) was prepared. The reducing sugar content was estimated using the following formula:

Reducing sugar content $(\%)=[($ titration $(\mathrm{mL})$ for blank - titration $(\mathrm{mL})$ for sample $) \times$ dilution factor $\times 0.1 \times 100] /$ sample weight $(\mathrm{g})$

\section{Statistical analysis}

This study employed a completely randomized design with four replications.
The effect of Dracaena angustifolia leaves aqueous extract addition level $(0 \%, 3 \%, 4 \%$, $5 \%$, and $6 \%$ ) on the variable tested was 
observed using one-way analysis of variance (ANOVA). Significant differences $(\mathrm{P}<0.05)$ of mean values among treatments were determined using Duncan's multiple range test.

\section{RESULTS AND DISCUSSION}

\section{Texture profile}

Hardness is one of variables that are used to determine the texture profile of food. The ANOVA revealed that the addition of Dracaena angustifolia leaves aqueous extract to milk toffee had significant effect $(\mathrm{P}<0.01)$ on the hardness of milk toffee. Higher addition level resulted in softer milk toffee (Table 1).

Milk toffee in this study is classified as a non-jelly soft/chewy candy according to BSN (2008) as it is made from whole milk containing fat and processed without aging. The hardness in Newton were ranged from 3.87 to 4.83 . The texture of milk toffee was softened by the addition of Dracaena angustifolia leaves aqueous extract. This was caused by the additional moisture content from the aqueous extract, the interactions between milk proteins and fatsoluble phenolic compounds, flavonoid compounds and chlorophylls, and the presence of fat from the main ingredient. Moisture and fat content govern the texture of non-jelly candies, i.e. the texture of candy progresses from runny, soft and chewy to hard and brittle as the moisture content decreases and emulsifier is not added (Ergun et al., 2010). High moisture content causes soft texture of the food materials (Muawanah et al., 2012). Anggraini and Hermansyah (2015) added that Dracaena angustifolia leaves aqueous extract does not have gelling properties. It is caused by the absence of hydrocolloid and gel-inducing compound (Indrasti et al, 2019). Additionally, glassy sugar on the surface of candy is also easily absorbing moisture. Although parchment paper was used to cover milk toffee in this study, crystalized sugar that underwent through glass transition on the surface of candy tends to be hygroscopic, thus absorbing moisture from the air (Ergun et al., 2010).

Table 1. The hardness (N) of milk toffee added with Dracaena angustifolia leaves aqueous extract

\begin{tabular}{cc}
\hline Addition level (\%) & Hardness (N) \\
\hline 0 & $4.83^{\mathrm{a}} \pm 0.06$ \\
3 & $4.50^{\mathrm{b}} \pm 0.10$ \\
4 & $4.33^{\mathrm{c}} \pm 0.06$ \\
5 & $4.10^{\mathrm{c}} \pm 0.10$ \\
6 & $3.87^{\mathrm{d}} \pm 0.06$ \\
\hline
\end{tabular}

Remarks: Data are presented as mean \pm standard deviation. ${ }^{\mathrm{a} \sim \mathrm{d}}$ Means within the same column are significantly different $(\mathrm{P}<0.05)$.

Table 2. The lightness (L* value) of milk toffee added with Dracaena angustifolia leaves aqueous extract

\begin{tabular}{cc}
\hline Addition level (\%) & $\mathrm{L}^{*}$ value \\
\hline 0 & $49.40^{\mathrm{a}} \pm 0.53$ \\
3 & $52.47^{\mathrm{b}} \pm 0.67$ \\
4 & $53.50^{\mathrm{bc}} \pm 0.53$ \\
5 & $54.43^{\mathrm{c}} \pm 0.40$ \\
6 & $56.40^{\mathrm{d}} \pm 0.53$ \\
\hline
\end{tabular}

Remarks: Data are presented as mean \pm standard deviation. ${ }^{\text {a d }}$ Means within the same column are significantly different $(\mathrm{P}<0.05)$. 
The soft texture of milk toffee is a result of the emulsification of milk fat, thus preventing the fat releases during thermal process. Milk proteins, whey and casein, play a significant role as emulsifier. They cover the fat droplets and all fat-soluble materials from being loss during thermal process.

Milk proteins are well-known for being utilized as functional compounds delivery as they can interact with fat-soluble materials and reduce the loss of their functionality during processing caused by high temperature exposure and oxidation (Tavares and Noreña, 2019). Chlorophyll is a liposoluble pigment with a low solubility in water (Indrasti et al., 2019). When thermal process applied, it will remain in the product and replace the bond between protein and moisture (Zhang et al., 2020). Therefore, higher addition of Dracaena angustifolia leaves aqueous extract prevents the loss of fat and soften the texture of milk toffee.

\section{Color}

Color is one of important food quality traits that attract consumer visually and influence the acceptability (Hutchings, 2003). Instrumental color variables: lightness $\left(\mathrm{L}^{*}\right)$, redness $\left(\mathrm{a}^{*}\right)$ and yellowness $\left(\mathrm{b}^{*}\right)$, are commonly measured using a color reader (Suyatma, 2009). The ANOVA revealed that the addition of Dracaena angustifolia leaves aqueous extract to milk toffee had significant effect $(\mathrm{P}<0.01)$ on the lightness $\left(\mathrm{L}^{*}\right)$, redness $\left(\mathrm{a}^{*}\right)$ and yellowness $\left(b^{*}\right)$ of milk toffee.
Higher addition level of Dracaena angustifolia leaves aqueous extract to milk toffee resulted in higher $\mathrm{L}^{*}$ value (Table 2). The $\mathrm{L}^{*}$ value ranged from 49.40 to 56.40 . The lightness of milk toffee is influenced by the addition of Dracaena angustifolia leaves aqueous extract as Natural food colorant. Garcia et al. (2000) mentioned that the lightness of sample is positively correlated with $\mathrm{L}^{*}$ value, which is in line with Amin (2014). The $L^{*}$ value of 100 represents brighter appearance, while the $\mathrm{L}^{*}$ value of 0 represents darker appearance (Muzaifa, 2013). The presence of chlorophyll in Dracaena angustifolia leaves aqueous extract altered the color of milk toffee. The color of control milk toffee was pale brown, while that of treatment groups was light green.

Higher addition level of Dracaena angustifolia leaves aqueous extract to milk toffee resulted in higher $a^{*}$ value (Table 3 ). The $\mathrm{a}^{*}$ value ranged from 6.77 to 8.83 . The redness of milk toffee is influenced by the thermal process and flavonoid content of Dracaena angustifolia leaves aqueous extract. Karlina et al. (2013) mentioned that solution containing flavonoid will appear red, orange or yellow when getting thermal abuse. Shabrina et al. (2018) added that the $a^{*}$ value of food product containing sugar increases when getting caramelized. The chlorophyll in Dracaena angustifolia leaves aqueous extract is a polar compound, as like flavonoid, it gets lighter (light green to yellowish) when being exposed by light or high temperature because of pigment thermal oxidation (Mlodzinska, 2009).

Table 3. The redness (a* value) of milk toffee added with Dracaena angustifolia leaves aqueous extract

\begin{tabular}{cc} 
aqueous extract & $\mathrm{a}^{*}$ value \\
\hline Addition level $(\%)$ & $6.77^{\mathrm{a}} \pm 0.32$ \\
3 & $8.23^{\mathrm{b}} \pm 0.06$ \\
4 & $8.40^{\mathrm{bc}} \pm 0.10$ \\
5 & $8.70^{\mathrm{bc}} \pm 0.10$ \\
6 & $8.83^{\mathrm{c}} \pm 0.06$ \\
\hline
\end{tabular}

Remarks: Data are presented as mean \pm standard deviation. ${ }^{\mathrm{a} \sim \mathrm{c}}$ Means within the same column are significantly different $(\mathrm{P}<0.05)$. 
Higher addition level of Dracaena angustifolia leaves aqueous extract to milk toffee resulted in higher $b^{*}$ value (Table 4). The $b^{*}$ value ranged from 18.60 to 23.17. The $b^{*}$ value represents blue and yellow. Negative $b^{*}$ value means the color of sample is close to blue, while positive $b^{*}$ value means the sample is more likely yellow. The yellowness of milk toffee is influenced by the thermal oxidation of flavonoids and chlorophyll of Dracaena angustifolia leaves aqueous extract. Munawaroh and Handayani (2010) mentioned that when the extract solution dominated by flavonoids and chlorophyll is thermally treated, the color of solution changes from dark green into light green (yellowish).

\section{Vitamin C content}

Dracaena angustifolia leaves aqueous extract contains chlorophyll, phenolic and flavonoid compounds that possess antioxidant capacity (Anggraini and Nabillah, 2018). The ANOVA revealed that the addition of Dracaena angustifolia leaves aqueous extract to milk toffee had significant effect $(\mathrm{P}<0.01)$ on vitamin $\mathrm{C}$ content in milk toffee.

Table 4. The yellowness (b* value) of milk toffee added with Dracaena angustifolia leaves aqueous extract

\begin{tabular}{cc}
\hline Addition level (\%) & $\mathrm{b}^{*}$ value \\
\hline 0 & $18.60^{\mathrm{a}} \pm 0.10$ \\
3 & $20.60^{\mathrm{b}} \pm 0.10$ \\
4 & $21.40^{\mathrm{c}} \pm 0.10$ \\
5 & $22.80^{\mathrm{d}} \pm 0.10$ \\
6 & $23.17^{\mathrm{e}} \pm 0.21$ \\
\hline
\end{tabular}

Remarks: Data are presented as mean \pm standard deviation. ${ }^{\mathrm{a} \sim \mathrm{e}}$ Means within the same column are significantly different $(\mathrm{P}<0.05)$.

Table 5. Vitamin C content (\%) of milk toffee added with Dracaena angustifolia leaves aqueous extract

\begin{tabular}{cc}
\hline Addition level (\%) & Vitamin C content \\
\hline 0 & $0.089^{\mathrm{a}} \pm 0.002$ \\
3 & $0.090^{\mathrm{a}} \pm 0.004$ \\
4 & $0.106^{\mathrm{b}} \pm 0.002$ \\
5 & $0.109^{\mathrm{b}} \pm 0.005$ \\
6 & $0.110^{\mathrm{b}} \pm 0.004$ \\
\hline
\end{tabular}

Remarks: Data are presented as mean \pm standard deviation. ${ }^{\mathrm{a}, \mathrm{b}}$ Means within the same column are significantly different $(\mathrm{P}<0.05)$.

Higher addition level of Dracaena angustifolia leaves aqueous extract to milk toffee resulted in higher vitamin $\mathrm{C}$ content (Table 5). There were no differences between control and milk toffee added with 3\% Dracaena angustifolia leaves aqueous extract on vitamin $\mathrm{C}$ content, both were lower than higher addition level groups, i.e. $4 \%$ to $6 \%$. Among higher addition level groups, there were no significant differences either. Jokopriyambodo et al. (2014) reported that Dracaena angustifolia leaves extract contains $2.7 \mathrm{mg} / \mathrm{kg}$ of vitamin C.
Further, whole milk contains vitamin C, when it gets pasteurized, the amount declines and remains approximately $591 \mu \mathrm{g} / \mathrm{g}$ (Fitasari et al., 2018). Agar-agar powder also contains vitamin $\mathrm{C}$ as it is made from seaweed. Vitamin $\mathrm{C}$ content of dried seaweed ranged from 100 to $800 \mathrm{mg} / \mathrm{kg}$ dry matter (Nianti et al., 2018). The use of agaragar powder in milk toffee making reduces the loss of nutrients, including antioxidant compounds. Agar-agar powder forms dispersed colloids and coats water-soluble nutrients in milk, thus prevent the oxidation 
or loss of vitamin $\mathrm{C}$ during thermal process (Nianti et al., 2018).

\section{Reducing sugar content}

Reducing sugars are derived from the hydrolysis of disaccharides such as sucrose, lactose and maltose. In this study, sucrose and lactose are the major sources of reducing sugars in milk toffee. Glucose, fructose and galactose are possible reducing sugars formed by thermal hydrolysis of sucrose and lactose. The ANOVA revealed that the addition of Dracaena angustifolia leaves aqueous extract to milk toffee had significant effect $(\mathrm{P}<0.01)$ on reducing sugar content in milk toffee.

Table 6. Reducing sugar content (\%) of milk toffee added with Dracaena angustifolia leaves aqueous extract

\begin{tabular}{cc}
\hline Addition level (\%) & Reducing sugar content \\
\hline 0 & $6.08^{\mathrm{a}} \pm 0.05$ \\
3 & $6.24^{\mathrm{ab} \pm 0.06}$ \\
4 & $6.32^{\mathrm{bc}} \pm 0.12$ \\
5 & $6.41^{\mathrm{bc}} \pm 0.02$ \\
6 & $6.53^{\mathrm{c}} \pm 0.09$ \\
\hline
\end{tabular}

Remarks: Data are presented as mean \pm standard deviation. ${ }^{\mathrm{a} \sim \mathrm{c}}$ Means within the same column are significantly different $(\mathrm{P}<0.05)$.

Higher addition level of Dracaena angustifolia leaves aqueous extract to milk toffee resulted in higher reducing sugar content (Table 5). However, among higher addition level groups, i.e. $4 \%$ to $6 \%$, there were no significant differences on reducing sugar content. The reducing sugar content ranged from $6.08 \%$ to $6.53 \%$. There are two factors affecting the hydrolysis of sucrose into glucose and fructose in confectionery, i.e. thermal process and the use of acid (Mandei, 2014).

As milk toffee was processed with thermal treatment, sucrose from sugar cane and lactose from the milk used were hydrolyzed into glucose, fructose and galactose. Further, the reducing sugars formed, and free amino acids of milk proteins underwent through glycation or Maillard reaction resulting a light brown or almost-caramelized appearance and bittersweet taste (Clemens et al., 2016). The longer the thermal process is carried out, the higher the concentration of reducing sugars is formed (Ameliya et al., 2018). Trissanthi and Susanto (2015) added that sucrose dissolved in water containing protein also go through Maillard reaction. In this study, the addition of Dracaena angustifolia leaves aqueous extract to milk toffee was responsible to the accumulation of reducing sugars. Dracaena angustifolia leaves are source of sugar as its powder consists of $86.01 \%$ carbohydrates and part of it is sucrose (Shukla et al., 2015). Sucrose is abundant in plants (Suwarno et al., 2015). Sucrose from Dracaena angustifolia leaves were also hydrolyzed during milk toffee making. The levels of reducing sugar in this study are also below the maximum limit $(20 \%)$ set by national standard for soft/chewy candy (BSN, 2008). Therefore, the addition of Dracaena angustifolia leaves aqueous extract at more than $3 \%$ up to $6 \%$ increased the reducing sugar content in milk toffee within acceptable range.

\section{CONCLUSION}

The addition of Dracaena angustifolia leaves aqueous extract to milk toffee softened the texture, intensified color by enhancing lightness $\left(\mathrm{L}^{*}\right)$, redness $\left(\mathrm{a}^{*}\right)$, and yellowness $\left(b^{*}\right)$, and increased vitamin $C$ and reducing sugar content. Therefore, the addition level of $6 \%$ of Dracaena angustifolia leaves aqueous extract is recommended to produce milk toffee with soft texture, intense color, and containing vitamin $\mathrm{C}$. 


\section{REFERENCES}

Al-Rawahi, A., Kasapis, S., \& Al-Bulushi, I. (2005). Development of a date confectionery: part 1. relating formulation to instrumental texture. International Journal of Food Properties, 8(3), 457-468. https:// doi.org/10.1080/10942910500267521

Ameliya, R., Nazaruddin, \& Handito, D. (2018). The effect of boiling time on vitamin c, antioxidant activity and sensory properties of Singapore cherry (Muntingia calabura L.) syrup. Jurnal Ilmu Dan Teknologi Pangan, 4(1), 289-297. https://doi.org/10.29303/pro food.v4i1.77

Amin, M. . (2014). Sukses Bertani Buncis. In Sayuran Obat Kaya Manfaat. Yogyakarta: Garudhawaca.

Amit, S. K., Uddin, M. M., Rahman, R., Islam, S. M. R., \& Khan, M. S. (2017). A review on mechanisms and commercial aspects of food preservation and processing. Agriculture \& Food Security, 6(1), 51. https://doi.org/10.11 86/s40066-017-0130-8

Andesna, Y., \& Elida, E. (2019). Pengaruh penambahan ekstrak daun pandan dan daun suji terhadap kualitas keripik sanjai lado hijau. Jurnal Kapita Selekta Geografi, 2(2), 90-100. https:// doi.org/10.24036/KSGEO.V2I2.168

Anggraini, D. I., \& Nabillah, L. F. (2018). Activity test of suji leaf extract (Dracaena angustifolia Roxb.) on in vitro cholesterol lowering. Jurnal Kimia Sains Dan Aplikasi, 21(2), 54-58. https: //doi.org/10.14710/jksa.21.2.54-58

Aryanti, N. (2016). Extraction and characterization of chlorophyl from suji leaves (Pleomele angustifolia) as natural food colorant. Jurnal Aplikasi Teknologi Pangan, 5(4), 129-135. https://doi.org/10.17728/jatp.196

Badan Standardisasi Nasional. (2008). Lunak. In Kembang gula (2nd ed.). Jakarta: Badan Standardisasi Nasional.

Clemens, R. A., Jones, J. M., Kern, M., Lee, S.-Y., Mayhew, E. J., Slavin, J. L., \& Zivanovic, S. (2016). Functionality of Sugars in Foods and Health. Comprehensive Reviews in Food Science and Food Safety, 15(3), 433470. https://doi.org/10.1111/1541-4337 .12194

Elok, E., Dwiloka, B., \& Setiani, B. E. (2018). The influence of suppleness, brightness, vitamin c and organoleptic properties of lemon rind jelly peel (Citrus medica var Lemon). Jurnal Teknologi Pangan, 2(1), 64-69. https://doi.org/10.14710/jtp.2.1.\%p

Ergun, R., Lietha, R., \& Hartel, R. W. (2010). Moisture and shelf life in sugar confections. Critical Reviews in Food Science and Nutrition, 50(2), 162-192. https://doi.org/10.1080/104 08390802248833

Faradillah, N. (2017). Characteristics of low calorie milk caramel candy by different proportion of sucrose and stevia sugar (Stevia rebaudiana). Jurnal Aplikasi Teknologi Pangan, 6(1), 39-42. https://doi.org/10.17728 /jatp.206

Fitasari, P., Syahrir, M., \& Mustarin, A. (2018). Diversifikasi produk susu pasteurisasi dengan penambahan sari buah jambu biji merah (Psidium gujava Linn). Jurnal Pendidikan Teknologi Pertanian, 4, 69-75. https: //doi.org/10.26858/jptp.v4i0.6914

Garcia, M. A., Martino, M. N., \& Zaritzky, N. E. (2000). Lipid addition to improve barrier properties of edible 
starch-based films and coatings. Journal of Food Science, 65(6), 941944. https://doi.org/10.1111/j.1365-26 21.2000.tb09397.x

Hayati, D. A., Ginting, N., Wahyuni, T. H., Mirwandhono, E. R., \& Hasnudi, H. (2018). Pemanfaatan Daun Kelor (Moringa oleyfera) Terhadap kandungan gizi pada permen karamel dari susu kambing. Talenta Conference Series: Agricultural and Natural Resources (ANR), 1(2), 192-197. https://doi.org/10.32734/anr.v1i2.236

Hutching, J. B. (2003). Food Colour and Appearance (2nd ed.). Gaithersburg: Aspen Publication, Inc.

Indrasti, D., Andarwulan, N., Hari Purnomo, E., \& Wulandari, N. (2019). Suji leaf chlorophyll: potential and challenges as natural colorant. Jurnal Ilmu Pertanian Indonesia, 24(2), 109-116. https://doi.org/10.18343/jipi.24.2.109

Jokopriyambodo, W. (2014). The antiradical activity of insoluble water suji (Pleomele angustifolia N.E. Brown) leaf extract and its application as natural colorant in bread product. Journal of Food and Pharmaceutical Sciences, 2(1), 27-31. https://doi.org/ $10.14499 /$ jps

Mandei, J. H. (2014). Composition of several sugar compounds in the making of nutmeg hard candy. Jurnal Penelitian Teknologi Industri, 6(2), 1-10. https:// doi.org/10.33749/JPTI.V6I2.3200

Marlina, M., Wijaya, M., \& Kadirman, K. (2019). Effect of addition of red dragon fruit (Hylocereus polyrhizus) to quality of milk caramel candy. Jurnal Pendidikan Teknologi Pertanian, 5(1), 85-97. https://doi. org/10.26858/jptp.v5i1.8199
Marrubini, G., Papetti, A., Genorini, E., \& Ulrici, A. (2017). Determination of the sugar content in commercial plant milks by near infrared spectroscopy and luff-schoorl total glucose titration. Food Analytical Methods, 10(5), 1556-1567. https://doi.org/10.1007/s 12161-016-0713-1

Mlodzinska, E. (2009). Survey of plant pigments: molecular and environmental determinants of plant colors. Acta Biologica Cracoviensia Series Botanica, 51(1), 7-16.

Muawanah, A., Djajanegara, I., Sa'duddin, A., Sukandar, D., \& Radiastuti, N. (2012). Penggunaan bunga kecombrang (Etlingera Elatior) dalam proses formulasi permen jelly. Jurnal Kimia VALENSI, 2(4), 526-533. https://doi.org/10.15408/jkv.v2i4.270

Mukaromah, U., Susetyorini, S. H., \& Aminah, S. (2010). Kadar vitamin C, mutu fisik, ph dan mutu organoleptik sirup rosella (Hibiscus Sabdariffa, L) berdasarkan cara ekstraksi. Jurnal Pangan Dan Gizi, 1(1), 43-51.

Munawaroh, S., \& Astuti, P. (2010). Ekstraksi minyak atsiri daun jeruk purut (Citrus hystrix D. C) dengan pelarut etanol dan N-Heksana. Kompetensi Teknik, 2(1), 73-78.

Muzaifa, M. (2013). Physic characteristics change of bilimbi during fermentation of asam sunti (traditional fermented bilimbi of Aceh). Jurnal Teknologi Dan Industri Pertanian Indonesia, 5(2), 7-11. https://doi.org/10.17969/ jtipi.v5i2.1002

Novelina, N., Anggraini, T., \& Hermansyah, R. (2015). Production of Liquid chlorophyll from the leaves of green grass jelly (Premna oblongifolia Merr.). 
International Journal on Advanced Science, Engineering and Information Technology, 5(5), 366-369. https://doi .org/10.18517/ijaseit.5.5.584

Özkan, G., \& Ersus Bilek, S. (2014). Microencapsulation of natural food olourants. International Journal of Nutrition and Food Sciences, 3(3), 145-156. https://doi.org/10.11648/j.ij nfs.20140303.13

Shabrina, Z. U., \& Susanto, W. H. (2018). Pengaruh suhu dan lama pengeringan dengan metode cabinet dryer terhadap karakteristik manisan kering apel varietas anna (Malus domestica Borkh). Jurnal Pangan Dan Agroindustri, 5(3), 60-71.

Shukla, A., Vats, S., \& Shukla, R. (2015). Phytochemical screening, proximate analysis and antioxidant activity of dracaena reflexa lam. leaves. Indian Journal of Pharmaceutical Sciences, 77(5), 640-644. https://doi.org/10.41 03/0250-474X.169035

Spínola, V., Mendes, B., Câmara, J. S., \& Castilho, P. C. (2013). Effect of time and temperature on vitamin C stability in horticultural extracts. UHPLC-PDA vs iodometric titration as analytical methods. LWT - Food Science and Technology, 50(2), 489-495. https:// doi.org/10.1016/j.lwt.2012.08.020

Suwarno, S., Ratnani, R. D., \& Hartati, I. (2015). Proses Pembuatan gula invert dari sukrosa dengan katalis asam sitrat, asam tartrat dan asam klorida. Jurnal Momentum UNWAHAS, 11(2), 99-103.
Suyatma. (2009). Diagram warna hunter (Kajian Pustaka). Jurnal Penelitian Ilmiah Teknologi Pertanian, 8-9.

Tavares, L., \& Zapata Noreña, C. P. (2019). Encapsulation of garlic extract using complex coacervation with whey protein isolate and chitosan as wall materials followed by spray drying. Food Hydrocolloids, 89, 360-369. https://doi.org/10.1016/j.foodhyd.201 8.10 .052

Trisshanti, C. M., \& Susanto, W. H. (2016). Pengaruh konsentrasi asam sitrat dan lama pemanasan terhadap karakteristik kimia dan organoleptik sirup alang-alang (Imperata cylindrica). Jurnal Pangan Dan Agroindustri, 4(1), 180-189.

Yudha, K. C. (2013). Aktivitas antibakteri ekstrak herba krokot (Portulaca oleracea L.) terhadap Staphylococcus aureus dan Escherichia coli. LenteraBio, 2(1), 87-93.

Zhang, Z.-H., Peng, H., Woo, M. W., Zeng, X.-A., Brennan, M., \& Brennan, C. S. (2020). Preparation and characterization of whey protein isolate-chlorophyll microcapsules by spray drying: Effect of WPI ratios on the physicochemical and antioxidant properties. Journal of Food Engineering, 267, 109729. https://doi. org/10.1016/j.jfoodeng.2019.109729 